\title{
Study of fetomaternal outcome in various modes of breech delivery in a tertiary care hospital- MGM GH, Trichy
}

\author{
Uma Mohanraj*, A. Adhirai
}

\begin{abstract}
Department of Obstetrics and Gynaecology, MGM GH, K.A.P.V. Government Medical College, Trichirappalli, Tamil
\end{abstract} Nadu, India

Received: 19 June 2019

Revised: 30 November 2020

Accepted: 01 December 2020

\author{
*Correspondence: \\ Dr. Uma Mohanraj, \\ E-mail: armohanraj87@gmail.com
}

Copyright: () the author(s), publisher and licensee Medip Academy. This is an open-access article distributed under the terms of the Creative Commons Attribution Non-Commercial License, which permits unrestricted non-commercial use, distribution, and reproduction in any medium, provided the original work is properly cited.

\begin{abstract}
Background: Aim of the study was to optimize the fetomaternal outcome using different modes of delivery in breech presentation and objective of the study was to optimize the maternal and perinatal outcome in various modes of breech delivery.

Methods: Among 150 mothers with different parity and gestational age having singleton breech were studied during May 2019- October 2019 for the period of 6 months at KAPV government medical college. Fetomaternal outcome was compared in various modes of breech delivery during this study period in our institute. This study was a prospective analytical study.

Results: Incidence of breech presentation was 3.3\% of total deliveries in this institute. Around 4 (26.6\%) cases by emergency LSCS, 48 (32\%) cases delivered vaginally, 62 (41.3\%) cases by elective LSCS. Comparatively, large number of cases were delivered by planned caesarean section in our institute. The maternal and perinatal morbidity and mortality was found to be less in planned caesarean section compared with other modes of delivery in this study.

Conclusions: In view of insignificant difference in the fetomaternal outcome balanced decision about mode of delivery on a case by case basis will go a long way in improving both fetal and maternal outcome. Regular drills and conduct of assisted vaginal breech delivery should be pursued in all maternity hospitals.
\end{abstract}

Keywords: Assisted breech delivery, Breech presentation, Caesarean section, Fetomaternal outcome, Perinatal outcome, Singleton breech

\section{INTRODUCTION}

Breech presentation is defined as a fetus in longitudinal lie with the caudal pole (buttocks or feet) occupying the lower part of uterus and cephalic pole in the uterine fundus. ${ }^{1}$ There are three types of breech presentation. In frank breech presentation (48\%-73\%), both hips are flexed and both knees are extended. In the complete breech position (4.6\%-11.5\%), both hips and knees are flexed. In the incomplete breech position (12.4\%-40.5\%), one or both hips are not completely flexed. ${ }^{2}$ Incidence of breech presentation at term (37-40 weeks) is $3-5 \%$ of singleton deliveries. The percentage of breech presentation decreases with advancing age from $22-25 \%$ at 28 weeks gestation to $7-15 \%$ at 32 weeks and is $3-4 \%$ at term. The incidence of breech at term is $3-4 \%$, although it is $7 \%$ at 32 weeks. $^{3-6}$

Predisposing factors for breech presentation include prematurity, uterine malformations, fibroids, polyhydramnios, placenta previa, fetal abnormalities (CNS malformations, neck mass, aneuploidy) and multiple gestation. In addition $19.4 \%$ of neonates undergoing term breech deliveries have long term morbidity upto school age irrespective of mode of delivery. ${ }^{7}$ ACOG and RCOG recommends that the decision regarding the mode of 
delivery should depend on the experience of the health care provider and that planned vaginal delivery of a term singleton breech fetus may be reasonable under hospital specific protocol guidelines.$^{8}$ The perinatal mortality and morbidity increases with breech presentation by 2-4 fold regardless of mode of delivery. A landmark multicentric randomized controlled study "The term breech trial" comparing planned caesarean versus planned vaginal birth by Dr. Hannah from 1997-2000, came to the conclusion among 2088 women, $90.4 \%$ delivered by caesarean section, $56.7 \%$ delivered by planned vaginal birth. Planned caesarean delivery was associated with a lower risk of perinatal mortality compared with planned vaginal delivery by 3 per 1000 versus 13 per 1000. Study concludes that planned caesarean is better than planned vaginal birth for the term breech. ${ }^{9}$

An overall policy of planned caesarean section in all term breeches would prevent complications of vaginal delivery but there would be no vaginal breech delivery. This might result in shifting of the contemporary art of conducting such delivery to the shelves of medical history. Proponents of term breech trial advocate elective caesarean section because of the concern for birth asphyxia and possibility of unexpected arrest of fetal parts at vaginal delivery. In contrast, other studies support vaginal delivery as a suitable option at term -Premoda study which translates as presentation and mode of delivery showed no differences in corrected neonatal mortality rates and neonatal outcomes according to delivery mode (Goffinet 2006). ${ }^{10}$ External cephalic version reduces the rate of noncephalic presentation at birth and ACOG recommends that version be offered and its success rate averages about $60 \% .{ }^{11}$ The present study was conducted with an objective to optimize the maternal and perinatal outcome in various modes of breech delivery.

\section{METHODS}

Among 150 mothers with different parity and various gestational age having singleton breech were studied under the prospective analytical study from May 2019 to October 2019 for the period of 6 months at KAPV government medical college, MGMGH, Trichy. Fetomaternal outcome was compared in various modes of delivery. On admission, the demographic profile of the women detailed menstrual and obstetric history were noted. General, systemic and obstetric examinations were carried out. All women were subjected to routine investigations and obstetric ultrasonography and they were assigned to either caesarean section (planned/emergency) or vaginal delivery on the basis of the obstetric examination (clinical and sonographical) and the presence of complicating factors.Women having standard indications of caesarean section in breech like fetopelvicdisproportion, hyperextension of the head, footling presentation, and associated complications (medical or obstetric) were assigned to the planned caesarean section group, whereas the remaining women having term breech were given a trial of assisted vaginal breech delivery. The plan of delivery for the both term and preterm breech was discussed with the women and their attendants the probable course and complication of vaginal delivery. A trial of assisted vaginal delivery was given to those who consented to it.

Regular drills of maneuvers in assisted vaginal breech delivery are conducted in our department. During a trial of assisted vaginal delivery, monitoring of fetal heart rate and progress of labor was done. Assisted breech delivery was the method of choice, maintaining a principle of non interference till the delivery of the scapula. The delivery of the extended arms was accomplished by Lovset's method, whereas the delivery of the after coming head was conducted by the Burns Marshall Method or Mauriceau Smellie Veit maneuver. After delivery, the baby was attended by the pediatrician and the Apgar Score at 1 and 5 min was noted and the baby was admitted to the neonatal intensive care unit if needed. If fetal distress and arrest of progress in labor were suspected, the women were taken for emergency caesarean section. All the mothers and newborns were followed up for 7 days in the postnatal period. Data regarding the fetomaternal outcome were analyzed. Comparisons were made in terms of morbidity and mortality between groups of mothers and infants stratified by the mode of delivery.

\section{RESULTS}

Most foetuses that present as breech before term turn spontaneously to cephalic presentation. The incidence decreases as the gestational age increases. The incidence of breech in the present study is $3.3 \%$ in our institution. Majority of antenatal mothers $50 \%$ belongs to $21-25$ years age group, 46 women belongs to age group 26- 30 years. 16 women were below 20 years and 13 were above 30 years.

Table 1: Age wise distribution of breech delivery in the study group.

\begin{tabular}{|lll|}
\hline Age $($ years $)$ & Cases $(\mathbf{n = 1 5 0})$ & Percentage \\
\hline $\mathbf{2 0}$ & 16 & 11 \\
\hline $\mathbf{2 1 - 2 5}$ & 75 & 50 \\
\hline $\mathbf{2 6 - 3 0}$ & 46 & 31 \\
\hline $\mathbf{3 1 - 3 5}$ & 11 & 7 \\
\hline $\mathbf{3 6}$ & 2 & 1 \\
\hline
\end{tabular}

Table 2: Parity in the study group.

\begin{tabular}{|lll|}
\hline Parity & Cases $(\mathbf{n}=\mathbf{1 5 0})$ & Percentage \\
\hline Primi & 88 & 59 \\
\hline Multi & 62 & 41 \\
\hline
\end{tabular}

Most of the mothers were primi (59\%) and rest were multigravida in this study group. In this study group, $51 \%$ of breech presentation was around 37-42 weeks, $26 \%$ was 33-36 weeks, $18 \%$ among 28-32 weeks, only 5\% seen more than 42 weeks. 
Table 3: Gestational age of breech delivery in the study group.

\begin{tabular}{|lll|}
\hline Gestational age (weeks) & Cases $(\mathbf{n = 1 5 0 )}$ & $\begin{array}{l}\text { Frequency } \\
(\%)\end{array}$ \\
\hline $\mathbf{2 8 - 3 2}$ & 27 & 18 \\
\hline $\mathbf{3 3 - 3 6}$ & 39 & 26 \\
\hline $\mathbf{3 7 - 4 2}$ & 76 & 51 \\
\hline $\mathbf{> 4 2}$ & 8 & 5 \\
\hline
\end{tabular}

Table 4: Number of referrals in the study group.

\begin{tabular}{|lll|}
\hline Study group & Cases $(\mathbf{n = 1 5 0 )})$ & $\begin{array}{l}\text { Frequency } \\
(\%)\end{array}$ \\
\hline Referral & 131 & 87 \\
\hline Self & 9 & 6 \\
\hline Others & 10 & 6 \\
\hline
\end{tabular}

In this study group, the total number of referral cases were 131 cases and $87 \%$ frequency. Self-group were $6 \%$ frequency and only 9 cases. Since our institution is tertiary care centre, number of referrals were high. If there is perstitence of breech presentation even after 37 weeks of pregnancy, many cases were reffered earlier and decision regarding the mode of delivery was planned earlier.

Table 5: Different types of breech presentation.

\begin{tabular}{|lll|}
\hline Types of breech & Cases $(\mathbf{n = 1 5 0 )}$ & $\begin{array}{l}\text { Frequency } \\
(\boldsymbol{\%})\end{array}$ \\
\hline Complete & 116 & 77 \\
\hline Frank/incomplete & 19 & 12 \\
\hline Footling & 12 & 8 \\
\hline Kneeing & 3 & 2 \\
\hline
\end{tabular}

In this study group, complete breech had higher frequency around $77 \%$ and 116 cases, frank breech 19 cases and $12 \%$ frequency, footling breech 12 cases and $8 \%$ (single footling 5 cases and double footling 7 cases), knee presentation (2\%) 3 cases were noted.

Table 6: Different modes of breech delivery.

\begin{tabular}{|lll|}
\hline $\begin{array}{l}\text { Mode of delivery } \\
\text { Assisted vaginal }\end{array}$ & 48 & $\begin{array}{l}\text { Frequency } \\
(\mathbf{\%})\end{array}$ \\
\hline $\begin{array}{l}\text { breech } \\
\text { Emergency LSCS }\end{array}$ & 40 & 32 \\
\hline Elective LSCS & 62 & 26.6 \\
\hline
\end{tabular}

Overall, 48 (32\%) women delivered vaginally, a majority of them were term cases. Planned caesarean section was done in 62 women $(41.3 \%)$ for which the indications were given below. $40(26.6 \%)$ women were delivered by emergency caesarean section for various indications. In our study, lesser number of women delivered by emergency LSCS (26.6\%) as compared to assisted breech delivery $(32 \%)$. Larger number of women in our study delivered by planned caesarean section (41.3\%) as compared to the assisted breech (32\%). A large number of assisted vaginal births (32\%) also provided us with the opportunity to train our residents to conduct different maneuvers in assisted vaginal breech delivery and to avoid caesarean section, thereby reducing operative burden upon the over-worked obstetrics units.

The most common indication for elective lscs in breech delivery was fetopelvic disproportion around 15 cases (24.1\%), second most common cause was previous lscs with 12 cases $(19.3 \%)$, next comes oligohydraminos 10 cases $(16 \%)$, contracted pelvis 8 cases $(12.9 \%)$,footling breech 7 cases (11.2\%), elderly primi 4 cases $(6.4 \%), \mathrm{BOH}$ 3 cases $(4.8 \%)$,kneeing 3 cases $(4.8 \%)$ respectively.

Table 7: Indications for elective LSCS in breech delivery.

\begin{tabular}{|l|l|l|}
\hline $\begin{array}{l}\text { Indication for elective } \\
\text { LSCS }\end{array}$ & $\begin{array}{l}\text { Cases } \\
(\mathbf{n = 6 2 )}\end{array}$ & $\begin{array}{l}\text { Frequency } \\
(\boldsymbol{\%})\end{array}$ \\
\hline Fetopelvic disproportion & 15 & 24.1 \\
\hline Previous C-S & 12 & 19.3 \\
\hline Oligohydraminos & 10 & 16.1 \\
\hline Contracted pelvis & 8 & 12.9 \\
\hline Footling breech & 7 & 11.2 \\
\hline Elderly primi & 4 & 6.4 \\
\hline BOH & 3 & 4.8 \\
\hline kneeing & 3 & 4.8 \\
\hline
\end{tabular}

Table 8: Indications for emergency LSCS in breech delivery.

\begin{tabular}{|lll|}
\hline $\begin{array}{l}\text { Indication for emergency } \\
\text { Lscs }\end{array}$ & $\begin{array}{l}\text { Cases } \\
(\mathbf{n = 4 0})\end{array}$ & $\begin{array}{l}\text { Frequency } \\
(\%)\end{array}$ \\
\hline Fetal distress & 16 & 40 \\
\hline Failure to progress & 14 & 35 \\
\hline Cord prolapse & 5 & 12.5 \\
\hline Footling & 5 & 12.5 \\
\hline
\end{tabular}

In emergency LSCSC fetal distress 16 cases (40\%) plays major cause, failure to progress 14 cases (35\%) and footling breech and cord prolapse both 5 cases occupies same frequency $(12.5 \%)$.

The incidence of overall neonatal morbidity was $6 \%$, out of which $4 \%$ was present in the assisted vaginal delivery group, but this subgroup was constituted mainly by preterm babies (5 out of 6). Damage to soft tissue was sustained equally for both the vaginal and emergency caesarean groups (2 each). Comparatively injuries were less in emergency LSCS. In case of planned caesarean section, neonatal morbidity found to be nil. Such damage can be attributed to the fact that delivering the infants even by caesarean section is essentially the process of breech extraction. None of the injuries were life threatening.

This shows the overall incidence of perinatal mortality in the present study was $18(12 \%)$, out of which 9 cases were found in the vaginal delivery with $6.2 \%$ term and $12.5 \%$ preterm deliveries. Nil fatality was found in the planned caesarean section group in contrast to 9 cases in the emergency caesarean section group. 
Table 9: Neonatal morbidity in relation with different modes of delivery.

\begin{tabular}{|c|c|c|c|c|c|c|c|}
\hline \multirow{2}{*}{ Neonatal morbidity } & \multirow{2}{*}{ No. of morbidity } & \multicolumn{2}{|c|}{ Vaginal $(n=48)$} & \multicolumn{2}{|c|}{ Planned C.S (n=62) } & \multicolumn{2}{|c|}{ Emergency C.S (n=40) } \\
\hline & & Term & Preterm & Term & Preterm & Term & Preterm \\
\hline Clavicle fracture & 2 & - & 1 & - & - & - & 1 \\
\hline Fracture humerus & 1 & - & 1 & - & - & - & \\
\hline Dislocation of hip & 1 & - & 1 & - & - & - & \\
\hline Erbs palsy & 1 & - & 1 & - & - & - & \\
\hline Soft tissue injuries & 4 & - & 2 & - & - & - & 1 \\
\hline Total & $9(6 \%)$ & $6(4 \%)$ & & & & $3(2 \%)$ & \\
\hline
\end{tabular}

Table 10: Perinatal mortality in relation to different modes of delivery.

\begin{tabular}{|c|c|c|c|c|c|c|c|}
\hline \multirow{2}{*}{$\begin{array}{l}\text { Causes of perinatal } \\
\text { mortality }\end{array}$} & \multirow{2}{*}{$\begin{array}{l}\text { No of } \\
\text { mortality }\end{array}$} & \multicolumn{2}{|c|}{ Vaginal $(n=48)$} & \multicolumn{2}{|c|}{ Planned C.S (n=62) } & \multicolumn{2}{|c|}{ Emergency C.S (n= 40) } \\
\hline & & Term & Preterm & Term & Preterm & Term & Preterm \\
\hline Birth asphyxia & 9 & 1 & 3 & - & - & 2 & 3 \\
\hline Prematurity & 5 & & 3 & - & - & & 2 \\
\hline $\begin{array}{l}\text { Intra uterine fetal } \\
\text { demise }\end{array}$ & 2 & 1 & - & - & - & 1 & \\
\hline $\begin{array}{l}\text { Intraventricular } \\
\text { heamorrhage }\end{array}$ & 1 & 1 & - & - & - & - & - \\
\hline Cord prolapse & 1 & & - & - & - & 1 & \\
\hline Total & 18 & 3 & 6 & & & 4 & 5 \\
\hline Frequency & $12 \%$ & $6.20 \%$ & $12.50 \%$ & & & $10 \%$ & $12 \%$ \\
\hline
\end{tabular}

In our study, the perinatal mortality seems to be equal in both the assisted vaginal delivery group and in emergency caesarean group, but lesser in planned caesarean group. Birth asphyxia and prematurity was the largest factor contributing to perinatal mortality. The planned caesarean group at term pregnancy had a significantly better perinatal outcome, but the emergency caesarean section group failed proving the same advantage. There was no maternal death in either group. Maternal morbidity in the caesarean section group was $2.3 \%$ and in the vaginal group, it was
$3.2 \%$ in this study. Maternal death is rare, but rates appear higher in those with planned caesarean delivery for breech presentation.

\section{DISCUSSION}

Perinatal mortality and neonatal morbidity, neonatal mortality were significantly lower for the planned caesarean section group than for the planned vaginal birth group as reported by the Term Breech Trial and others. ${ }^{12,13}$

Table 11: Comparison table of fetomaternal outcomes in different studies.

\begin{tabular}{|c|c|c|c|c|c|c|c|c|c|}
\hline \multirow{3}{*}{ Authors } & \multirow{3}{*}{ Years } & \multirow{3}{*}{$\begin{array}{l}\text { No. of } \\
\text { women }\end{array}$} & \multicolumn{3}{|c|}{ Mode of delivery } & \multicolumn{2}{|c|}{ PN Morbidity } & \multicolumn{2}{|c|}{$\begin{array}{l}\text { Neonatal } \\
\text { mortality }\end{array}$} \\
\hline & & & Vaginal & \multicolumn{2}{|l|}{ CS } & Vaginal & CS & Vaginal & CS \\
\hline & & & 691 & $\begin{array}{l}\text { Planned } \\
941(452 \%)\end{array}$ & $\begin{array}{l}\text { Emergency } \\
451(21.6 \%)\end{array}$ & & & $5.0 \%$ & $1.6 \%$ \\
\hline Giuliani et al & 2002 & 699 & - & - & - & $2.3 \%$ & $0.5 \%$ & 0 & 0 \\
\hline Gilbert et al & 2003 & $1,00,730$ & $\begin{array}{l}4,952 \\
(4.91 \%)\end{array}$ & $\begin{array}{l}60,418 \\
(60 \%)\end{array}$ & $\begin{array}{l}35,297 \\
(35.1 \%)\end{array}$ & $\begin{array}{l}5.7-33.9 \\
(\mathrm{OR})\end{array}$ & & $\begin{array}{l}9.2 \\
\text { (OR) }\end{array}$ & \\
\hline Jukka et al & 2003 & 986 & $455(46.1 \%)$ & $396(40.2 \%)$ & $135(13.7 \%)$ & $1.2 \%$ & $0.5 \%$ & - & $\begin{array}{lll}- \\
-\end{array}$ \\
\hline Bassaw et al & 2004 & 344 & $187(54.3 \%)$ & $157(45.7 \%)$ & & $2.6 \%$ & $0.6 \%$ & $1.2 \%$ & $0.3 \%$ \\
\hline
\end{tabular}

Our study is also in accordance with them, due to the opportunity of earlier referral to plan the mode of delivery before labor is provided to the obstetrician in a referral hospital like ours and emergency caesarean section yielded comparable results in terms of perinatal outcome, as a point also made by others. ${ }^{14-16}$ We therefore recommend a very balanced decision regarding the mode of delivery in the tertiary centers of developing countries. Breech presentation at any gestational age is associated with higher perinatal morbidity and mortality than vertex presentation irresepective of mode of delivery. Obstetric management of breech presentation at term is not uniform and it is a controversial discussed issue whether a caesarean or a vaginal delivery is to be recommended. 
Although, almost universally accepted planned caesarean section to be better for the perinatal outcome than other modes of delivery, this Table depicts the comparable data of various studies after the Term Breech trial and shows a gradually increasing trend toward vaginal breech delivery gradually increasing trend toward vaginal breech delivery.

The role of maternal parity, pregnancy duration, perinatal morbidity are analysed. The analysis showed that not only the fetal birth weight but also other factors are responsible for elevated caesarean section rates. The limitations of this study is that the acquired data was based on single centre. The outcome of vaginal breech delivery depends on obstetricians expertise. The vaginally intended breech deliveries will be implemented into clinical practice it needs more education and growing number of hospitals offering a vaginal birth approach. The assisted vaginal breech delivery is accomplished in this study after proper selection, counseling and consent for women with breech presentation.

\section{CONCLUSION}

The Planned caesarean section is undoubtedly better than other mode of deliveries. In countries where the majority of caesarean sections for breech presentation are done in emergency, a trial of assisted vaginal delivery yields comparable results. Obstetricians, midwives and other healthcare workers conducting deliveries should receive a continuous medical education to be updated on how to conduct vaginal breech deliveries and how to resuscitate asphyxiated newborn. Therefore, it is concluded that the balanced decision about the mode of delivery on a case by case basis as well as conduct, training, and regular drills of different maneuvers in assisted breech delivery will go a long way to optimize the outcome of breech presentation in developing countries like ours.

Funding: No funding sources

Conflict of interest: None declared

Ethical approval: The study was approved by the Institutional Ethics Committee

\section{REFERENCES}

1. Alan H, Decherney M, Lauren MN. Current Diagnosis and Treatment Obstetrics and Gynaeecology,11th edition. 2007.

2. Steven G, Gabe RJ, Jeo M, Simpson L. Obstetrics Normal and Problem Pregnancies. 5th edition. 2007.
3. Warke HS, Saraogi RM, Sanjanwalla SM. Should a preterm breech go for vaginal delivery or caesarean section. J Postgrad Med. 1999;45:1-4.

4. Meye JF, Mayi S, Zue AS. Neonatal prognosis for breech infants delivered vaginally at the Josephine Bongo Maternity hospital in Libreville Garbon. Sante Avril. 2003;13:81-4.

5. Abasiattai AM, Etuk SJ, Asuquo EEJ. Perinatal outcome following singleton vaginal breech delivery in the University of Calabar Teaching Hospital, Calabar: a 10 year review. Mary Slessor J Med. 2004;4:81-5.

6. Gilbert WM, Hicks SM. Vaginal versus caesarean delivery for breech presentation in California: a population-based study. Obstet Gynaecol. 2003;102:911-7.

7. Mortality P, Okehukwu AP. Outome of singleton term breech deliveries at a university teaching hospital in eastern nigeria outcome of singleton term breech deliveries at a university teaching hospital in eastern Nigeria. Obstet Gynaecol. 2011;2(12):1-12.

8. American college of Obstetrics and Gynaecologists : Operative vaginal delivery. Practice Bulletin. Available at https://www.acog.org/clinical/clinicalguidance/practice-bulletin/ articles/ 2020/ 04/ operative-vaginal-birth. Accessed on 10 July 2020.

9. Hannah ME, Hannah WJ. Planned caesarean section versus planned vaginal birth for breech presentation at term: a randomized multicentre trial. Lancet. 2000;356:1375-83.

10. Goffinet F, Carayol M, Foidart JM. Is planned vaginal delivery for breech presentation at term still an option. Am J Obset Gynecol. 2006;194:1002-11.

11. American college of Obstetrics and Gynaecologists, Society for maternal Fetal Medicine ; Safe prevention of the primary caesarean delivery. Available at https:// www.acog.org/ clinical/ clinical-guidance/ obstetriccare-consensus/articles/2014/03/safe-prevention-ofthe-primary-cesarean-delivery. Accessed on 10 July 2020.

12. Bushra R, Tayyaba A. Maternal and perinatal outcome in term singleton breech presentation. J Postgrad Med Inst. 2004;18:373-379.

13. Nordin NM. An audit of singleton breech deliveries in a hospital with a high rate of vaginal delivery. Malays J Med Sci. 2007;14:28-37.

14. Giuliani A, Scholl WMJ, Basver A, et al. Mode of delivery and outcome of 699 term singleton breech deliveries at a single center. AJOG. 2002; 187:1664-8.

15. Bassaw B, Ramprasad N, Roopnarainesingh S. Correlation of fetal outcome with mode of delivery for breech presentation. J Obstet Gynaecol. 2004;24:254-8.

16. Uotila J, Tuimala R, Kirkinen P. Good perinatal outcome in selective vaginal breech delivery at term. Acta Obstet Gynecol Scand. 2005;84:578-83.

Cite this article as: Mohanraj U, Adhirai A. Study of fetomaternal outcome in various modes of breech delivery in a tertiary care hospital- MGM GH, Trichy. Int J Reprod Contracept Obstet Gynecol 2021;10:154-8. 